\title{
DIGITAL BADGES: ADDING PROFESSIONAL VALUE TO A FULLY ONLINE UNDERGRADUATE EDUCATIONAL TECHNOLOGY MINOR
}

\author{
Joseph Rene Corbeil, The University of Texas Rio Grande Valley, rene.corbeil@utrgv.edu \\ Maria Elena Corbeil, The University of Texas Rio Grande Valley, mariaelena.corbeil@utrgv.edu \\ Ignacio E. Rodriguez, The University of Texas Rio Grande Valley, ignacio.corbeil@utrgv.edu
}

\begin{abstract}
In gaming, business, and now, education, digital badges are being implemented to add value to informal and formal learning experiences. Digital badges are an easy way for learners to demonstrate the skills they have mastered through participation in a variety of educational and professional development activities. In order to help students and graduates showcase specific skills to employers, program faculty of a fully online undergraduate Educational Technology minor implemented digital badges through a three-phase study. The purpose of the study was to: determine students' knowledge and perceptions of digital badges before their implementation (Phase 1); integrate digital badges into the courses to determine if they positively impact learner motivation and improve academic achievement (Phase 2); and evaluate whether earned badges provide graduates with a competitive advantage when applying for jobs or advancing in current jobs (Phase 3). This article presents the results of the Phase 1 survey, as well as a status report for the first semester of Phase 2. Since Phase 2 involved the implementation of the digital badge initiative, a guide for implementing digital badges, including recommendations for software applications for designing and issuing digital badges is included.
\end{abstract}

Keywords: Digital Badges, E-Learning, Educational Technology, Corporate Training, Online Learning, Professional Development

\section{INTRODUCTION}

Badges that are awarded and showcased electronically are a significant change from traditional badges that are carried by law enforcement officials to represent their authority, or are worn on uniforms as exemplifications of skill mastery (ex.: Girl or Boy Scouts badges). According to the MacArthur Foundation (2016), "[d]igital badges are an assessment and credentialing mechanism that is housed and managed online. Badges are designed to make visible and validate learning in both formal and informal settings, and hold the potential to help transform where and how learning is valued" (para. 1). The transformative value of digital badges began in the world of gaming. While gaming skills and accomplishments were recognized previously, the video game industry was revolutionized when, in 2005, Microsoft introduced an easy-to-use system for recognizing achievement in its Xbox 360 gaming system (Wikipedia, n.d.).

The use of digital badges beyond gaming was first introduced through a paper written jointly by experts at Peer 2 Peer University and The Mozilla Foundation in 2011. That same year, the United States Secretary of Education, Arne Duncan, helped promote the digital badge movement by noting, "[b]adges can help speed the shift from credentials that simply measure seat time, to ones that more accurately measure competency. We must accelerate that transition. And, badges can help account for formal and informal learning in a variety of settings" (as cited in Parker, 2015, para. 1). The news caught on and articles started presenting different perspectives on the issue, as well as examples of the application of digital badges, especially in K-12 summer camps and other programs.

Proponents observed that digital badges would become popular at all levels of education because they could be "earned for a wide variety of reasons in multiple learning spaces, including after-school programs, summer workshops, K-12 classrooms, and universities" (Ash, 2012, para. 1). According to Ash (2012), the online representations of specific achievements are especially valuable because they are easily showcased throughout the learners' lifetime in a variety of online venues, making digital badges one of the few, easily accessible ways to connect early education with university and professional learning experiences. 
Today, over 3 years later, digital badges are still being talked about as holding exciting opportunities for informal and formal learning at all levels. In an article titled, Digital Badges as Effective Assessment Tools, published by the National Institute for Learning Outcomes Assessment, Parker (2015) observed that digital badges can help educators and employers "...assess skills that we do not normally assess in more traditional forms of content-based assessment...Badges could paint a more granular and meaningful picture of what a student actually knows than a standardized-test score or a letter grade" (para. 3). It is no surprise then, that a myriad of organizations are implementing digital badges, ranging from MIT and Yale, to NASA, the Smithsonian, and the U.S. Department of Education (Opperman, 2015).

In addition, digital badges can easily be added to social media sites, websites, and professional networking services, such as LinkedIn. "Digital badges serve as symbols of job-specific achievements that solidify an individual's membership in their professional community. They also afford individuals the opportunity to demonstrate incremental growth along a lifelong learning path that can lead to advancement and promotion" (Opperman, 2015, para. 5).

Given the excitement surrounding the opportunities digital badges provide for showcasing formal and informal educational and corporate-based learning, the faculty of a fully online, undergraduate Educational Technology minor, decided to explore the implementation of digital badges in a three-phase study. The purpose of the study was to: determine students' knowledge and perceptions of digital badges before their implementation (Phase 1); integrate digital badges in the courses and determine if they helped increase learner motivation to perform better academically (Phase 2); and evaluate whether earned badges increased graduates' competitive advantage when applying for jobs or advancing in current jobs (Phase 3). This article will present the results of the Phase 1 survey, as well as a status report for the first semester of Phase 2. Since Phase 2 involved the implementation of the digital badge initiative, a guide for implementing digital badges, including recommendations for software applications for designing and issuing digital badges is included. It will conclude with a look ahead to Phase III of the study, where the long-term impact of digital badges on graduates will be evaluated.

\section{PHASE I: SURVEY OF UNDERGRADUATE EDUCATIONAL TECHNOLOGY STUDENTS}

Phase I of the study was designed to help the Educational Technology faculty determine students' knowledge of, and perceptions regarding the use of digital badges to increase learner motivation and provide them with a competitive employment advantage. The Phase I survey was conducted prior to the implementation of the digital badges to see if there was a positive student response to the use of digital badges in their undergraduate courses. The following research questions were addressed:

- Research Question 1: To what extent do undergraduate Educational Technology students value digital badges as motivators in their academic coursework?

- Research Question 2: To what extent do undergraduate Educational Technology students believe digital badges can give them a competitive advantage in current or future employment?

After obtaining Human Subjects approval, an announcement with a welcome message and a link to the informed consent form were posted on the Announcements page of each of the 6 online undergraduate Educational Technology courses during the Spring and Summer 2015 semesters. When students clicked on the "I agree" option of the consent form, they were led to a web page that contained information about the digital badge initiative. Before starting the survey, students watched a brief video that introduced digital badges and their uses. They were then directed to a link to the Phase I survey.

Of the total 104-student population enrolled in six undergraduate Educational Technology courses, 48 students (46\%) volunteered to participate in the survey. The survey was comprised of three sections: Section I- Demographic Questions; Section II- Likert Scale Survey Questions; and Section III- Open-Ended Survey Questions. The results for each section are presented below. 


\section{Section I: Demographic Data}

The survey demographic data revealed that of the participants, $54 \%(n=26)$ were female, $46 \%(n=22)$ were male. A majority of the students, $79 \%(n=38)$ were Hispanic; $15 \%(n=7)$ were White, non-Hispanic; $4 \%(n=2)$ were African American; and 2\% ( $\mathrm{n}=1)$ identified themselves as Other. Regarding employment status, a majority, 73\% (n $=35)$ reported working full time; $13 \%(\mathrm{n}=6)$ worked part-time; and $14 \%(\mathrm{n}=7)$ were not employed. Their ages ranged from 18 to 60 , with $31 \%$ being $26-30$, and the next range being 31-35 (19\%). Table 1 below presents a detailed breakdown of the participant demographic information.

Table 1. Demographic Information $(\mathrm{N}=48)$

\begin{tabular}{ccc}
\hline Gender & Percentage & Number \\
\hline Male & $54 \%$ & 26 \\
Female & $46 \%$ & 22 \\
\hline Ethnicity & & \\
\hline Hispanic & $79 \%$ & 38 \\
White, Non-Hispanic & $15 \%$ & 7 \\
African American & $4 \%$ & 2 \\
Other & $2 \%$ & 1 \\
\hline Employment Status & & \\
\hline Full-Time & $73 \%$ & 35 \\
Part-Time & $13 \%$ & 6 \\
Not Employed & $14 \%$ & 7 \\
\hline Age Range & & 8 \\
\hline $18-25$ & $17 \%$ & 15 \\
$26-30$ & $31 \%$ & 9 \\
$31-35$ & $19 \%$ & 4 \\
$36-40$ & $8 \%$ & 3 \\
$41-45$ & $6 \%$ & 2 \\
$46-50$ & $4 \%$ & 5 \\
$51-55$ & $11 \%$ & 2 \\
$56-60$ & $4 \%$ &
\end{tabular}

\section{Section II: Student Perceptions of Digital Badges}

In Section II of the survey, students were asked to weigh in on their perceptions of digital badges and their value. Participants were asked to indicate to what extent they agreed with each of the five statements (Q1 - Q5) presented in Table 2 below. 
Table 2. Phase I Survey Results by Question $(\mathrm{N}=48)$

\begin{tabular}{|c|c|c|c|c|c|c|c|}
\hline Survey Item & $\begin{array}{c}\text { Strongly } \\
\text { Agree }\end{array}$ & Agree & $\begin{array}{c}\text { Somewhat } \\
\text { Agree }\end{array}$ & Neutral & $\begin{array}{c}\text { Somewhat } \\
\text { Disagree }\end{array}$ & Disagree & $\begin{array}{l}\text { Strongly } \\
\text { Disagree }\end{array}$ \\
\hline $\begin{array}{l}\text { Q1. I would like the } \\
\text { opportunity to earn a digital } \\
\text { badge to recognize my } \\
\text { mastery of course-related } \\
\text { skills and knowledge. }\end{array}$ & $\begin{array}{c}71 \% \\
34\end{array}$ & $\begin{array}{c}21 \% \\
10\end{array}$ & $\begin{array}{c}2 \% \\
1\end{array}$ & $\begin{array}{c}6 \% \\
3\end{array}$ & & & \\
\hline $\begin{array}{l}\text { Q2. The opportunity to earn } \\
\text { a digital badge would } \\
\text { motivate me to work harder } \\
\text { in my EdTech courses. }\end{array}$ & $\begin{array}{c}65 \% \\
31\end{array}$ & $\begin{array}{c}17 \% \\
8\end{array}$ & $\begin{array}{c}8 \% \\
4\end{array}$ & $\begin{array}{c}4 \% \\
2\end{array}$ & $\begin{array}{c}4 \% \\
2\end{array}$ & $\begin{array}{c}2 \% \\
1\end{array}$ & \\
\hline $\begin{array}{l}\text { Q3. Digital badges could } \\
\text { give me a competitive } \\
\text { advantage in current job or } \\
\text { when applying for a new } \\
\text { job. }\end{array}$ & $\begin{array}{c}65 \% \\
31\end{array}$ & $\begin{array}{c}15 \% \\
7\end{array}$ & $\begin{array}{c}10 \% \\
5\end{array}$ & $\begin{array}{c}4 \% \\
2\end{array}$ & $\begin{array}{c}4 \% \\
2\end{array}$ & $\begin{array}{c}2 \% \\
1\end{array}$ & \\
\hline $\begin{array}{l}\text { Q4. Digital badges can } \\
\text { emphasize the attainment of } \\
\text { skills that may otherwise be } \\
\text { hidden from prospective } \\
\text { employers. }\end{array}$ & $\begin{array}{c}75 \% \\
36\end{array}$ & $\begin{array}{c}15 \% \\
7\end{array}$ & $\begin{array}{c}2.08 \% \\
1\end{array}$ & $\begin{array}{c}8.33 \% \\
4\end{array}$ & & & \\
\hline $\begin{array}{l}\text { Q5. If I was an employer, I } \\
\text { would consider digital } \\
\text { badges included on an } \\
\text { applicant's resume. }\end{array}$ & $\begin{array}{c}58.33 \% \\
28\end{array}$ & $\begin{array}{c}25 \% \\
12\end{array}$ & $\begin{array}{c}6.25 \% \\
3\end{array}$ & $\begin{array}{c}6.25 \% \\
3\end{array}$ & $\begin{array}{c}2.08 \% \\
1\end{array}$ & $\begin{array}{c}2.08 \% \\
1\end{array}$ & \\
\hline
\end{tabular}

The results of the survey indicated that overall, students were genuinely interested in digital badges and found value in them. For example, 92\% (44) of the participants responded Strongly Agree/Agree that they would like the opportunity to earn a badge (Q1) in their courses.

Similarly, there was a positive response of Strongly Agree/Agree $(81 \%, \mathrm{n}=39)$ for the question regarding how the opportunity to earn a badge would motivate them to work harder in their Educational Technology courses (Q2). Different from Question 1, where no students responded with any of the Disagree options, 3 students (6\%) responded Somewhat Disagree/Disagree. The program faculty conferred on these results, noting that many of the students in the program were intrinsically motivated and did not require extrinsic rewards to motivate them to work harder in their courses. In fact, in one of the responses to the open-ended questions, one student wrote:

Brilliant idea!! A majority of 4-year schools are moving to do this. However, this would not have an effect on how hard I work in my course. Whether a badge is awarded or not, I strive to do my best.

The survey results also revealed that $79 \%(\mathrm{n}=38)$ of the students perceived that earned digital badges could afford them a competitive advantage in their current or future jobs (Q3). Only three students $(6 \%)$ disagreed with the statement responding Somewhat Disagree/Disagree. Interestingly, the results for this question broke down with exactly the same percentage and number of respondents as Question 2 regarding motivation (4\% Somewhat Disagree and 2\% Disagree), corresponding to 2 students and 1 student respectively for both questions (See Table 2 above). Although the survey was anonymous, the program faculty re-reviewed the results and found that on the same surveys where the motivation question was Somewhat Disagree/Disagree, the responses to Q3 about the competitive advantage of digital badges were identical, leading them to believe that the same students who responded that digital badges would not motivate them more, also disagreed that the digital badges could give them a competitive edge.

Question 4 asked students to rate how much they agreed or disagreed with the statement that digital badges could emphasize the attainment of skills that may otherwise be hidden from prospective employers. Nearly $90 \%(\mathrm{n}=43)$ 
strongly agreed or agreed. For this statement, no students responded to any of the disagree items on the scale.

The last question Q5, asked students to put themselves in the place of an employer and state if they would consider digital badges included on an applicant's resume. Forty students $(83 \%)$ responded Strongly Agree/Agree. Four percent (2 students) responded Somewhat Disagree/Disagree.

\section{Section III: Open-Ended Questions}

In Section III, two open-ended questions were presented to enable students to elaborate on their prior responses. The student responses provided additional insight regarding their perceptions of the value of digital badges. When asked, "What do you think of the use of digital badges to recognize mastery of specific course-related skills and knowledge?" most responses were positive. Presented below is a representative sample of their responses:

I think digital badges would motivate some of the students to work harder, and earning a digital badge does prove that you have mastered some of the skills that will be required when looking for a job.

The badge will not only show that you have earned it but will reflect upon the hard work and dedication of the skills and knowledge you have acquired through the course whether it has to do with a project, discussion, communication and collaboration in the course.

I'm not sure how widely used or recognized digital badges are in my field, but I don't think it would hurt to have such a badge regardless. It could help set me apart as an applicant for jobs.

Depending on the line of work, digital badges could be beneficial especially in a technology work environment.

Interestingly, a couple of students expressed hesitation, noting:

I think that at one point, people may have so many badges that they will not matter.

I think it is good in theory, but in practice [it] has a lot of potential issues, such as abuse of badge creation, having others earn the badges for you, regulation of requirements to earn a badge, and the people seeing the badges may not know what they are looking at or their relevance.

Most responses were also positive for open-ended question 2: Do you think employers would consider digital badges in employment decisions? Students responded:

Digital badges will be featured as add-ons and show, that you as the student, not only have taken courses and obtained badges, but they will also reflect on the hard work you had to do to receive the badges. I believe it will show employers, the skills and knowledge you have obtained throughout the coursework.

Two students responded positively, but noted interesting exceptions.

I think they would consider them, but they would not necessarily be the deciding factor.

It's a great incentive to promote growth in school, but in a real-life and in a highly technical job like mine, I believe that Degrees and Certificates from well-known organizations matter more. It could be used as a training incentive for students, but not in the work place.

Encouraged by the overwhelmingly positive student interest in digital badges as reflected through the Phase I survey, the Educational Technology faculty moved on to Phase II, the implementation of the digital badge initiative. 


\section{PHASE II: IMPLEMENTATION OF THE EDTECH DIGITAL BADGE INITIATIVE}

The implementation phase, which will be carried out over a period of one academic year, consists of five phases: (1) identify the skills and badge criteria; (2) design the digital badges; (3) inform students of the commencement of the digital badge initiative; (4) award badges at the end of the semester; and (5) integrate the earned digital badges into students' e-portfolios, resumes, and professional social media profiles. Since Phase 2 involved the implementation of the digital badge initiative, a guide for implementing digital badges, including recommendations for the selection of services for designing and awarding the badges will be included in this section. At the conclusion of the first semester of the digital badge implementation, a follow-up survey was implemented to determine if students' perceptions regarding the digital badge initiative had changed since the initial Phase I survey was administered. The results of the follow-up survey will also be presented in this section.

\section{Step 1: Identify Skills and Badge Criteria}

Before the digital badges could be designed, a review of the curriculum for the six undergraduate Educational Technology courses was initiated. For each course, program faculty identified one key skill that could be showcased through a digital badge. The selected skills were highly marketable, highly sought after skills that employers might look for in potential candidates. Once the skills were identified, the criteria for earning the digital badges were determined and a description was written for each. Educational Technology students could earn badges in the following areas: (1) Instructional Design; (2) Web-Based Instruction; (3) Multimedia Development; (4) Digital Collaboration; (5) Social Media Networking; and (6) EdTech Leadership. Table 3 below presents the digital badge titles, skill descriptions, and criteria for each badge.

Table 3. Digital Badge Titles, Skill Descriptions, and Criteria

\begin{tabular}{|c|c|}
\hline Badge Title and Description & Criteria for Earning a Digital Badge \\
\hline $\begin{array}{l}\text { Instructional Design: Students will use the ADDIE } \\
\text { model to develop a training manual on how to } \\
\text { perform a complex process or procedure. }\end{array}$ & $\begin{array}{l}\text { Students must earn a } 96 \text { or higher in EDTC } 3320 \text { - Instructional } \\
\text { Design for the Corporate Trainer. Students in this class will use the } \\
\text { ADDIE Instructional Design process to develop a training manual } \\
\text { that teaches individuals how to perform a complex procedure, } \\
\text { process, or use a software application. }\end{array}$ \\
\hline $\begin{array}{l}\text { Web-Based Instruction: Students will identify a } \\
\text { real-world training need or opportunity and develop a } \\
\text { Web-Based Training Module. }\end{array}$ & $\begin{array}{l}\text { Students must earn a } 96 \text { or higher in EDTC } 3321 \text { - Computer/Web- } \\
\text { Based Training. Students in this class will conduct a needs } \\
\text { assessment to identify a real-world training need or opportunity and } \\
\text { use the ADDIE Instructional Design process to develop a Web- } \\
\text { Based Training Module to address that need or opportunity. }\end{array}$ \\
\hline $\begin{array}{l}\text { Multimedia Development: Students will develop } \\
\text { effective interactive multimedia presentations for } \\
\text { web-based training or professional development. }\end{array}$ & $\begin{array}{l}\text { Students must earn a } 96 \text { or higher in EDTC } 3323 \text { - Designing } \\
\text { Instructional Multimedia. Students in this class will use a variety of } \\
\text { authoring programs to develop effective and interactive multimedia } \\
\text { presentations for web-based training or professional development. }\end{array}$ \\
\hline $\begin{array}{l}\text { Digital Collaboration: Students will use computer- } \\
\text { mediated communication to collaborate, share, and } \\
\text { deliver effective instruction to virtual learners. }\end{array}$ & $\begin{array}{l}\text { Students must earn a } 96 \text { or higher in EDTC } 3325 \text { - Computer } \\
\text { Mediated Communication and Collaboration. Students in this class } \\
\text { will use of computer-mediated communication (CMC) and } \\
\text { computer-supported collaborative learning (CSCL) in online } \\
\text { learning environments to collaborate, share, and deliver effective } \\
\text { instructional resources and instruction to virtual learners. }\end{array}$ \\
\hline $\begin{array}{l}\text { Social Media Networking: Students will establish a } \\
\text { professional profile on a social networking site and } \\
\text { link to EdTech organizations and practitioners. }\end{array}$ & $\begin{array}{l}\text { Students must earn a } 96 \text { or higher in EDTC } 3310 \text { - Introduction to } \\
\text { Educational Technology. Students in this class will establish a } \\
\text { professional profile on a social networking site and build a network } \\
\text { by linking to multiple educational technology related organizations } \\
\text { and persons. }\end{array}$ \\
\hline $\begin{array}{l}\text { EdTech Leadership: Students will develop an e- } \\
\text { learning solution to address an actual } \\
\text { instructional/training problem in a real-world context. }\end{array}$ & $\begin{array}{l}\text { Students must earn } 96 \text { or higher in EDTC } 3332 \text { - Instructional } \\
\text { Technology Practicum. Students in this class will reflect upon } \\
\text { major concepts, synthesize the knowledge base, and demonstrate } \\
\text { appropriate use of applications toward the solution of an actual } \\
\text { instructional/training problem in a real-world context. }\end{array}$ \\
\hline
\end{tabular}




\section{Step 2: Design Digital Badges}

After the badge titles, descriptions, and criteria were developed, it was time to design the digital badges. The Educational Technology faculty began by examining the badge creation tools available through the Blackboard Learning Management System, since it was the university's distance education delivery platform. They also experimented with a variety of free, web-based tools, including sites like Achievery (achievery.com), Badge List (badgelist.com), Credly (credly.com), and Open Badge Designer (openbadges.me). In the end, they selected Open Badge Designer because it enabled them to develop professional looking badges with minimal graphic design knowledge or effort. Figure 1 below presents a screenshot of the Badge Designer web site. Aside from its userfriendly interface, the faculty liked the ability of Badge Designer to let them view and edit the badges in real-time.

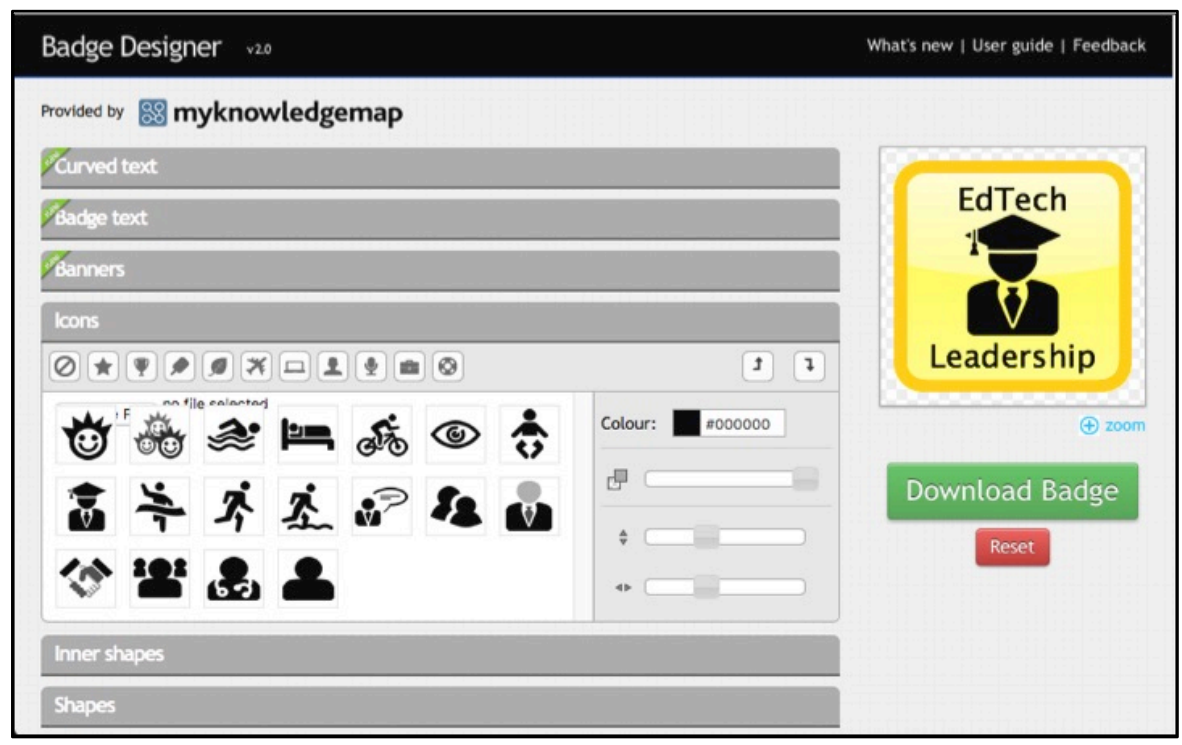

Figure 1. Screen Shot of the Badge Designer Interface

Figure 2 below presents the six badge icons that were created.

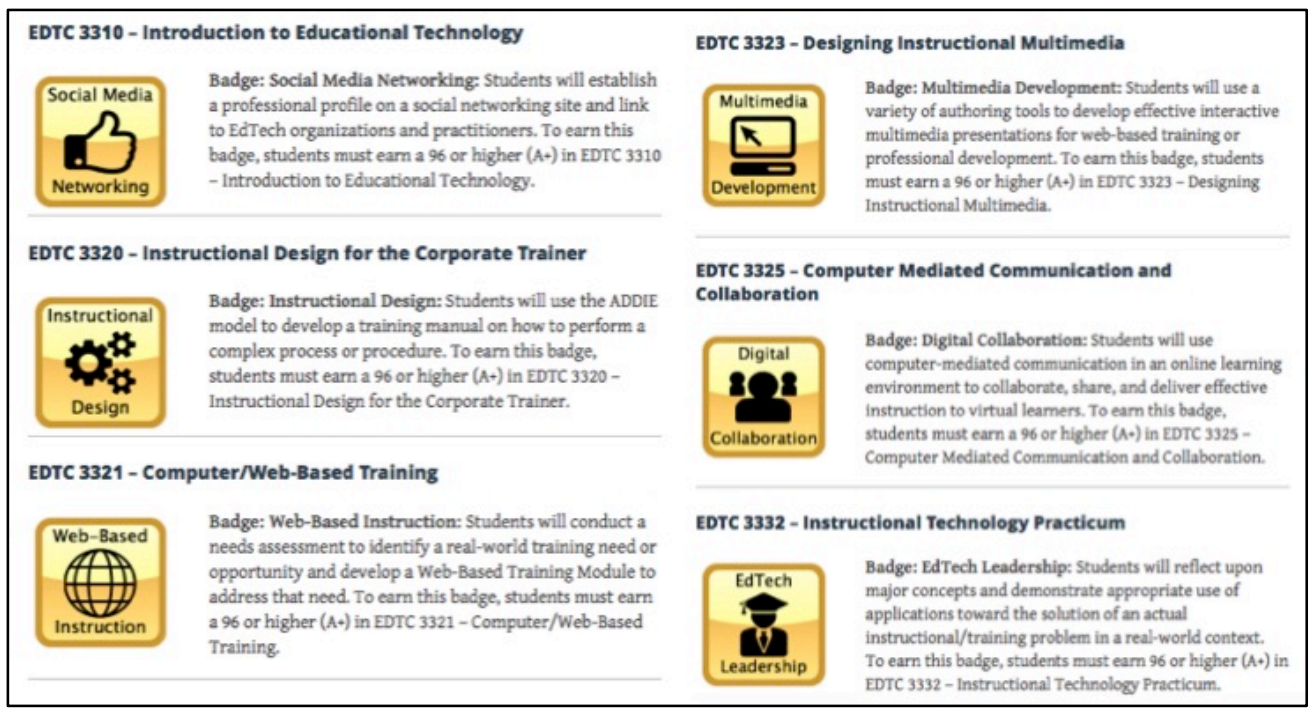

Figure 2. Images and Descriptions of the Six Educational Technology Digital Badges 


\section{Step 3: Inform Students}

Informing students of the commencement of the digital badge initiative involved a two-step process. First, the badge icons were added to the six Educational Technology courses' Home/Announcements pages (see Figure 3 below). The Home/Announcements page is the first thing students see when they login to their courses, so the badge icons located on the right menu bar serve as a constant reminder of their availability to interested students. The badge icon includes a hyperlink to the digital badge initiative web site. This site includes a comprehensive description of the initiative, as well as descriptions of the six badges and the criteria for earning them, instructions on how to collect earned badges, and a step-by-step guide for integrating earned badges into students' e-portfolios, resumes, and professional social media profiles. Figure 3 below presents a screenshot of a Home/Announcements page depicting the digital badge icon on the right menu bar.

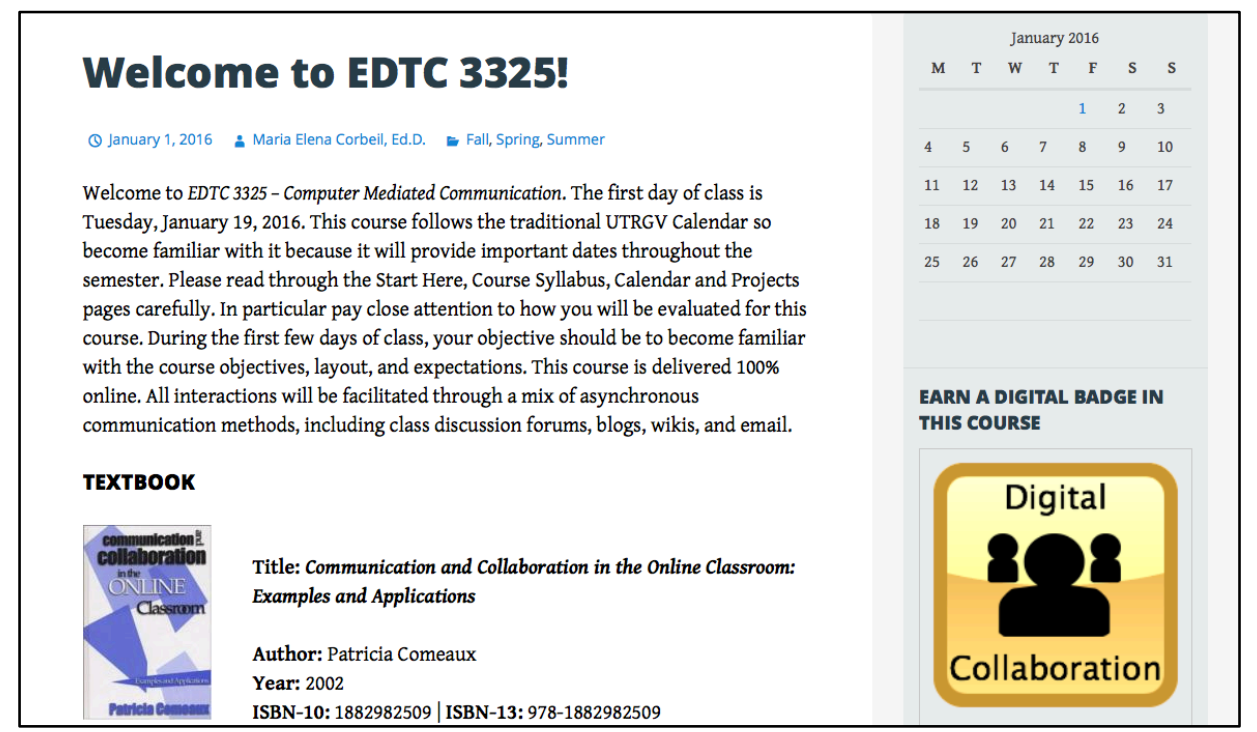

Figure 3. Screen Shot of the Right Menu Bar on the Course Announcements Page

The second step involved adding the digital badge information, including the badge description and criteria to the course Syllabi (see Figure 4 below).

\section{Earn a Digital Badge in this Course}

The Educational Technology program has adopted the use of digital badges for its undergraduate EdTech specialization courses. Students who excel in specific skills through their academic coursework will become eligible to earn a digital badge in the following area. This badge can be added your E-Portfolio, professional social media networking account (i.e., LinkedIn), and resume. Click on the following link to learn more about the digital badge initiative.

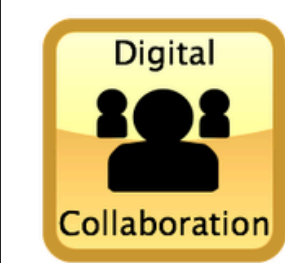

Badge: Digital Collaboration: Students will use computermediated communication in an online learning environment to collaborate, share, and deliver effective instruction to virtual learners. To earn this badge, students must earn a 96 or higher in EDTC 3325 - Computer Mediated Communication and Collaboration.

Figure 4. Screen Shot of the Section of the Course Syllabus that Describes the Digital Badge 


\section{Step 4: Award Digital Badges}

To award the badges, the faculty explored several free and open source platforms, beginning with Mozilla's Open Badges platform (openbadges.org). They also looked at Achievery (achievery.com), Credly (credly.com) and ClassBadges (classbadges.com). Although Mozilla's Open Badges platform was, by far, the most recognized platform, the faculty found the process for awarding and collecting badges through the Open Badges platform too cumbersome to be practical. If they wanted their students to participate in the digital badge initiative, the process for collecting earned badges had to be easy. For this reason, they selected ClassBadges as their badge delivery platform.

The ClassBadges web site was user friendly and set up was very easy. After registering for an account, the faculty set up their classes and input the digital badge information. Figure 5 below presents a screenshot of the ClassBadges interface.

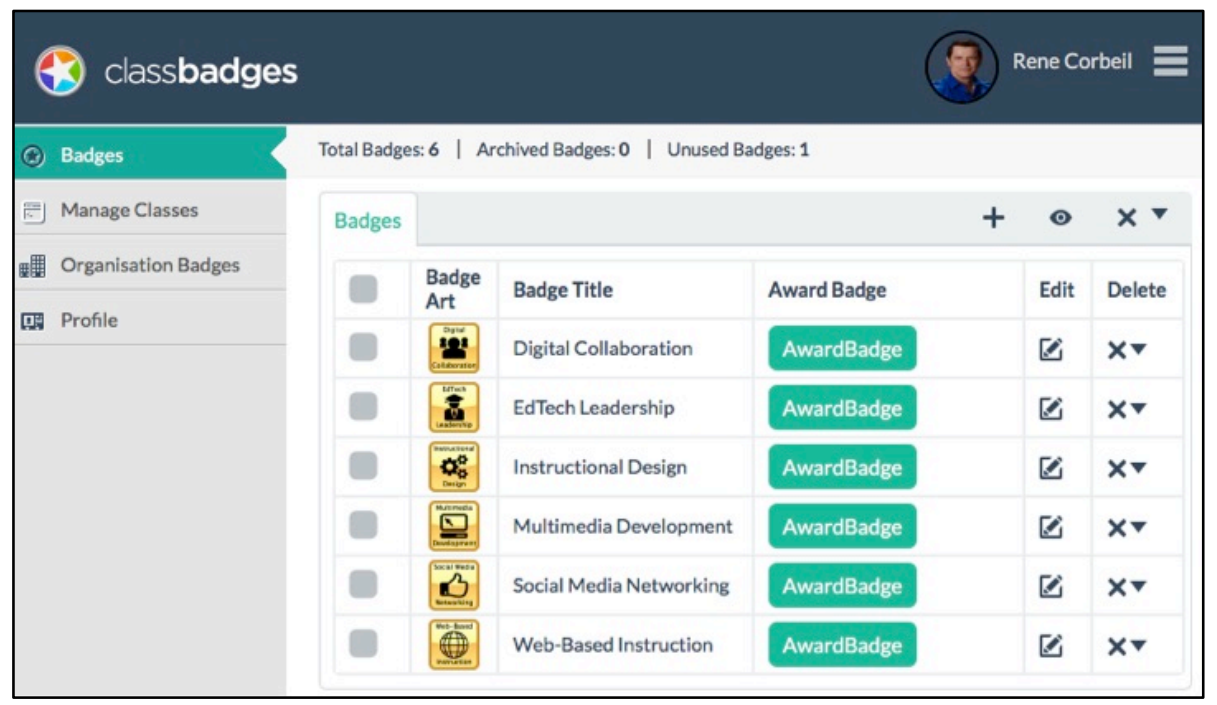

Figure 5. Screen Shot of the ClassBadges Interface Displaying the Six Educational Technology Badges

One of the advantages of ClassBadges is that digital badges can be issued one at a time or as a group. The quickest way to award badges to a large group is to create an Excel file for each class with the awardees first names, last names, and email addresses. Then, upload the Excel course files to the corresponding digital badges. Figure 6 below presents a screenshot of the ClassBadges upload page. 


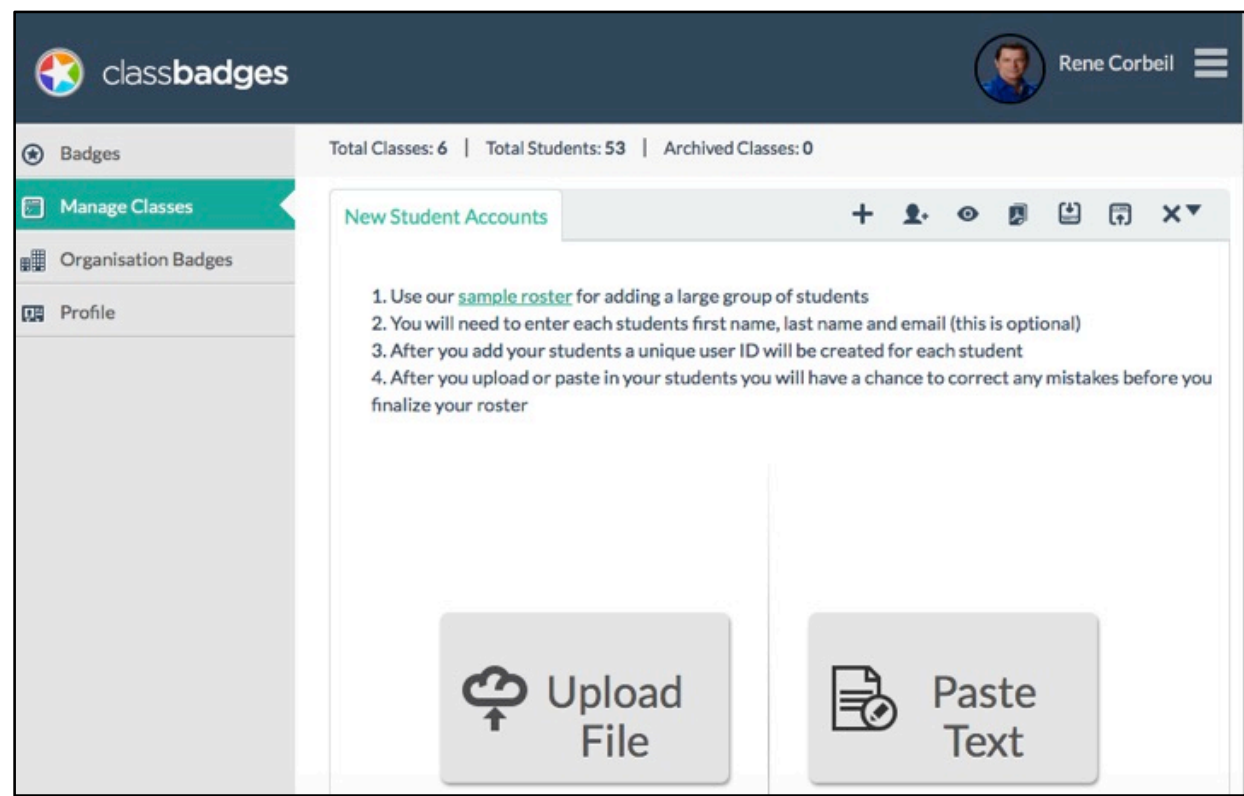

Figure 6. Screen Shot of the ClassBadges Upload Interface

\section{Step 5: Integrate Digital Badges in the Students' E-Portfolios}

The final step involved notifying students of the issuance of one or more earned digital badges. As soon as a badge has been awarded, ClassBadges sends badge earners an automatic email informing them of their award(s). This message is editable by the badge issuer, making it easy for faculty to include a hyperlink to step-by-step instructions for integrating the earned badges into students' e-portfolios, resumes, and professional social media profiles. Figure 7 below presents a sample Educational Technology student e-portfolio with images of the earned badges appearing on the Home page.

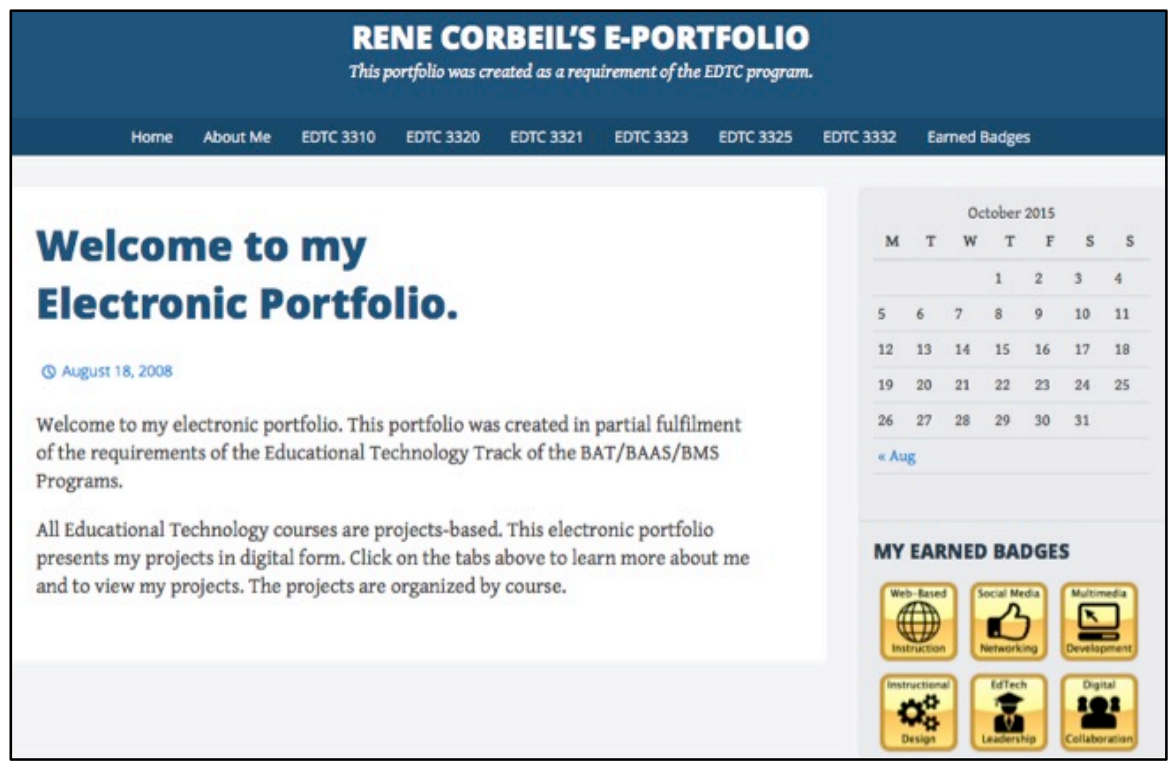

Figure 7. Screen Shot of a Sample E-Portfolio with Detailed Instructions 


\section{PHASE II: SURVEY RESULTS}

At the end of the Spring 2016 semester, a follow-up survey was administrated to badge earners to determine if their perceptions regarding digital badges had evolved since the initial Phase I survey. The informed consent form was made available, and those who clicked "I agree" were taken to the survey. During the Spring 2016 semester, 53 digital badges were awarded to 27 students, who completed the Phase II follow-up survey. Table 7 below presents the questions and responses for digital badge earners.

Table 7. Phase II Survey Results by Question ( $\mathrm{N}=27)$ Administered Only to the 27 Badge Earners

\begin{tabular}{|c|c|c|c|c|c|c|c|}
\hline Survey Item & $\begin{array}{c}\text { Strongly } \\
\text { Agree }\end{array}$ & Agree & $\begin{array}{c}\text { Somewhat } \\
\text { Agree }\end{array}$ & Neutral & $\begin{array}{c}\text { Somewhat } \\
\text { Disagree }\end{array}$ & Disagree & $\begin{array}{l}\text { Strongly } \\
\text { Disagree }\end{array}$ \\
\hline $\begin{array}{l}\text { Q1. I appreciated the opportunity } \\
\text { to earn a digital badge to } \\
\text { recognize my mastery } \\
\text { of course-related skills \& } \\
\text { knowledge. }\end{array}$ & $\begin{array}{c}59 \% \\
16\end{array}$ & $\begin{array}{c}26 \% \\
7\end{array}$ & $\begin{array}{c}7 \% \\
2\end{array}$ & $\begin{array}{c}4 \% \\
1\end{array}$ & & $\begin{array}{c}4 \% \\
1\end{array}$ & \\
\hline $\begin{array}{l}\text { Q2. The opportunity } \\
\text { to earn a digital badge motivated } \\
\text { me to work harder in my EdTech } \\
\text { courses. }\end{array}$ & $\begin{array}{c}59 \% \\
16\end{array}$ & $11 \% 3$ & $\begin{array}{c}15 \% \\
4\end{array}$ & $\begin{array}{c}7 \% \\
2\end{array}$ & & $\begin{array}{c}4 \% \\
1\end{array}$ & $\begin{array}{c}4 \% \\
1\end{array}$ \\
\hline $\begin{array}{l}\text { Q3. Digital badges will give me a } \\
\text { competitive advantage in current } \\
\text { job or when applying for a new } \\
\text { job. }\end{array}$ & $\begin{array}{c}52 \% \\
14\end{array}$ & $\begin{array}{c}22 \% \\
6\end{array}$ & $\begin{array}{c}11 \% \\
3\end{array}$ & $\begin{array}{c}11 \% \\
3\end{array}$ & & $\begin{array}{c}4 \% \\
1\end{array}$ & \\
\hline $\begin{array}{l}\text { Q4. Digital badges emphasize the } \\
\text { attainment of skills } \\
\text { that may otherwise be hidden } \\
\text { from prospective employers. }\end{array}$ & $\begin{array}{c}52 \% \\
14\end{array}$ & $\begin{array}{c}30 \% \\
8\end{array}$ & $\begin{array}{c}7 \% \\
2\end{array}$ & $\begin{array}{c}11 \% \\
3\end{array}$ & & & \\
\hline $\begin{array}{l}\text { Q5. If I was an employer, I would } \\
\text { consider digital badges included } \\
\text { on an applicant's resume. }\end{array}$ & $\begin{array}{c}52 \% \\
14\end{array}$ & $\begin{array}{c}30 \% \\
8\end{array}$ & $\begin{array}{c}7 \% \\
2\end{array}$ & $\begin{array}{c}7 \% \\
2\end{array}$ & $\begin{array}{c}4 \% \\
1\end{array}$ & & \\
\hline $\begin{array}{l}\text { Q6. I intend to incorporate my } \\
\text { earned badge(s) into my resume, } \\
\text { social media profile, \& } \\
\text { E-portfolio. }\end{array}$ & $\begin{array}{c}56 \% \\
15\end{array}$ & $\begin{array}{c}22 \% \\
6\end{array}$ & $\begin{array}{c}7 \% \\
2\end{array}$ & $\begin{array}{c}11 \% \\
3\end{array}$ & & $\begin{array}{c}4 \% \\
1\end{array}$ & \\
\hline $\begin{array}{l}\text { Q7. The Educational Technology } \\
\text { program should continue to award } \\
\text { digital badges } \\
\text { to recognize mastery of course- } \\
\text { related skills } \\
\text { \& knowledge. }\end{array}$ & $\begin{array}{c}59 \% \\
16\end{array}$ & $\begin{array}{c}22 \% \\
6\end{array}$ & $\begin{array}{c}7 \% \\
2\end{array}$ & $\begin{array}{c}11 \% \\
3\end{array}$ & & & \\
\hline
\end{tabular}

When asked if they appreciated the opportunity to earn a digital badge to recognize their mastery of course-related skills and knowledge, $59 \%$ of badge earners strongly agreed and $26 \%$ agreed, for a total agreement of $85 \%$. When asked if the opportunity to earn a digital badge motivated them to work harder in the Educational Technology courses, $59 \%$ of badge earners strongly agreed and $11 \%$ agreed for a total agreement to $70 \%$. When asked if digital badges would give badge earners a competitive advantage when applying for a new job, $52 \%$ of badge earners strongly agreed and $22 \%$ agreed, for a total agreement of $74 \%$. Similarly, when asked if digital badges emphasized the attainment of skills that may otherwise be hidden from prospective employers, $52 \%$ of badge earners strongly agreed and $30 \%$ agreed, for a total agreement of $82 \%$. When asked if they would consider digital badges on applicants' resumes, $52 \%$ of badge earners strongly agreed and $30 \%$ agreed, for a total agreement of $78 \%$.

In addition to the preceding outcomes, $78 \%$ of badge earners indicated they would integrate their badges into their e-portfolios, resumes, and professional social media profiles, and $72 \%$ would like the Educational Technology program to continue to award digital badges through their courses. 


\section{Discussion}

This three-phase study sought to determine whether digital badges served as motivators for students to encourage them to work harder in their courses, and to what extent they gave students a competitive advantage when applying for a job. While Phase I was completed at the end of the Fall 2015 semester, Phase II will continue through the 2016 Summer and Fall semesters. Over the next two semesters, the Educational Technology faculty will continue to issue badges and survey badge earners. At the end of the Phase II implementation year, the faculty will be in a better position to assess the efficacy of using digital badges to heighten undergraduate student motivation in their fully online courses. This paper provides a status report on the progress made thus far.

Figures 8 and 9 below present in summary form the results of the initial and follow-up surveys from Phases I and II. While the response rates to the five questions were higher in the initial survey, the responses of badge earners in the follow-up survey were still overwhelmingly positive. Of the total 104 students enrolled in the six, undergraduate Educational Technology minor courses during the Fall 2015 semester, 48 students (46\%) chose to participate in the initial survey. At the end of the Spring 2016 semester, 53 digital badges were awarded to 27 students. These 27 badge earners also participated in the follow-up survey.

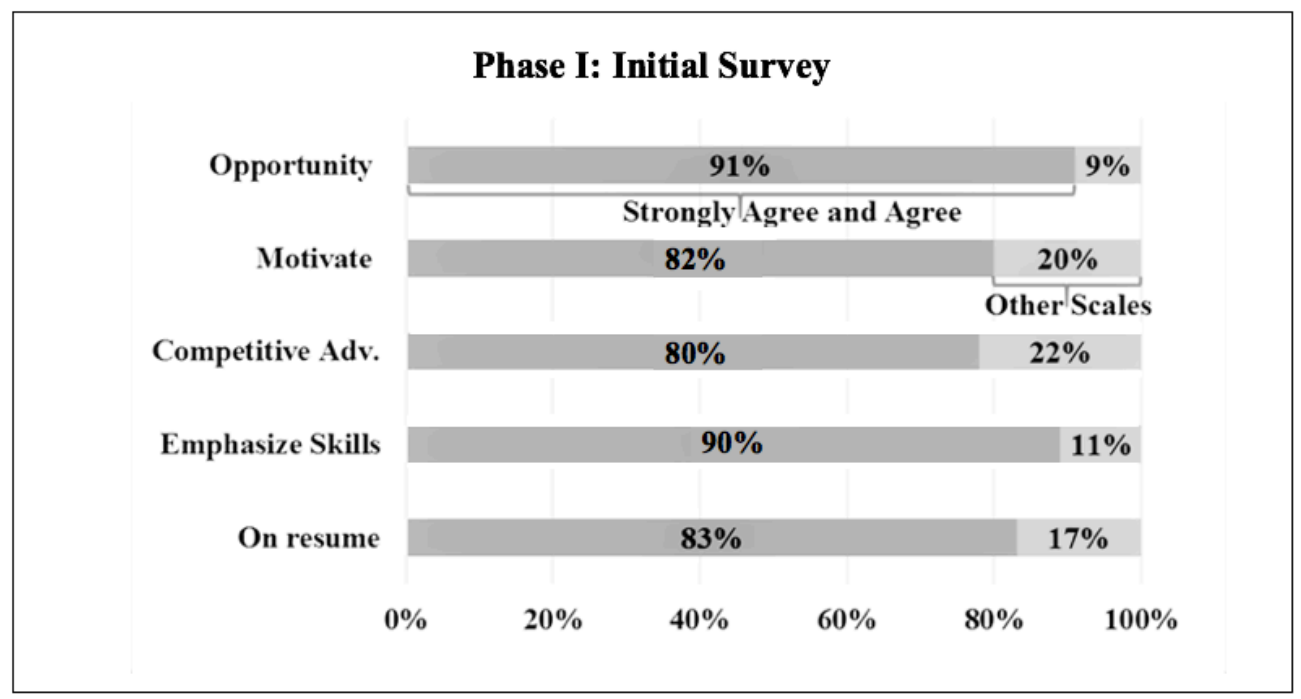

Figure 8. Survey Responses to Phase I: Initial Survey $(\mathrm{N}=48)$

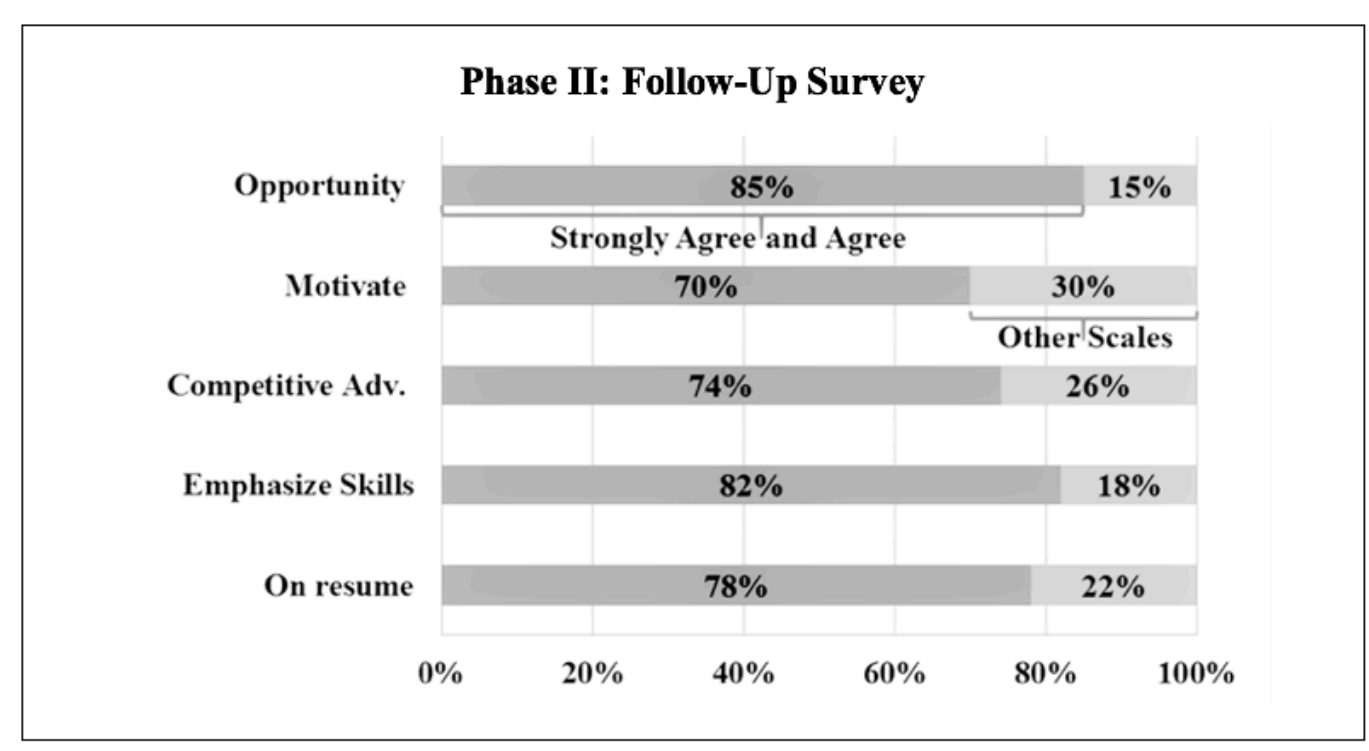


Figure 9. Survey Responses to Phase II: Follow-Up Survey $(\mathrm{N}=27)$

With regard to the opportunity to earn a digital badge, $91 \%$ of initial survey respondents and $85 \%$ of actual badge earners in the follow-up survey indicated a desire to earn a digital badge through their Educational Technology courses. One student from the initial survey observed:

I think students who excel in project-based classwork, should be rewarded for above average mastery of the subject matter - especially if the work is performed as if it were being produced for a client.

Regarding the perceived motivational benefits of digital badges, $82 \%$ of initial survey respondents and $70 \%$ of actual badge earners in the follow-up survey thought that digital badges would motivate them to work harder in their courses. Interestingly, only 1 participant disagreed with this statement in the initial survey, and another, strongly disagreed with it in the follow-up survey. In the follow-up survey, the student noted:

The statement about the opportunity of a digital badge made me work harder is far from the truth for me. I work hard in all of my courses. Whether a badge is awarded or not, I always strive to do my best.

Regarding the perceived competitive advantage of digital badges on future employment, $80 \%$ of initial survey respondents and $74 \%$ of actual badge earners believed that digital badges could give them a competitive advantage with the caveat that employers would know what they were and valued them. As one student from the initial survey observed:

I think [digital badges] could be a minor consideration in employment decisions, which could set an applicant apart from other applicants with similar skills and experience.

Regarding the emphasis of skills, $90 \%$ of initial survey respondents and $82 \%$ of actual badge earners believed that digital badges could emphasize skills that may otherwise be hidden from prospective employers. As one student from the initial survey noted:

Considering my profession, I think this is a great way to market graduates who are moving to the workforce. Employers not only look at resumes but these badges will be like a highlight of the skills and qualities graduates have.

Lastly, when asked if they, as employers, would consider earned badges, $83 \%$ of initial survey respondents and $78 \%$ of actual badge earners indicated that they would consider them on applicants' resumes. As one student from the initial survey noted:

[E]mployers will use any reliable information to differentiate between applicants. Everything an applicant brings to a job interview is worth consideration, and badges could offer some valuable insight even if they are not considered heavily weighted data as of yet.

\section{SUMMARY}

In early 2015, the researchers proposed a three-phase study (Corbeil, Corbeil, \& Rodriguez, 2015) to study students' interests in the integration of digital badges in their fully online, undergraduate Educational Technology minor courses, as well as their perceptions of their professional value. Since then, Phase I, and the first semester of Phase II have been completed and 53 digital badges have been awarded. Phase II will continue through the summer and fall 2016 semesters. Phase III will begin once the students who have earned badges graduate, in order to assess the impact of the earned digital badges on their professional careers. Opperman (2015) observed, "our modern era is characterized by a rapidly changing economy that requires members of the workforce to continuously seek [learning and development] L\&D opportunities" (para. 2). She added, "[e]arning a certificate or degree from a postsecondary institution is only the beginning of a lifelong learning process that includes recertification and professional development" (para. 2). Therefore, it is the expectation that the digital badge initiative will help students and graduates showcase the professional value of their Educational Technology minor to current and future employers. 


\section{Issues in Information Systems}

Volume 17, Issue III, pp. 124-137, 2016

\section{REFERENCES}

Ash, K. (2012). 'Digital badges' would represent students' skill acquisition. Education Week Digital Directions. Retrieved from: http://www.edweek.org/dd/articles/2012/06/13/03badges.h05.html

Corbeil, M. E., Corbeil, J. R., \& Rodriguez, I. E. (2015). Digital badges in higher education: A three-phase study on the implementation of digital badges in an online undergraduate program. Issues in Information Systems, 16(IV), pp. 1-9.

MacArthur Foundation. (2016). Digital badges. Retrieved from: https://www.macfound.org/programs/digital-badges

Microsoft. (2005). R., Bach, J. Allard, Peter Moore: Electronic Entertainment Expo (E3) 2005. Retrieved from: https://news.microsoft.com/2005/05/16/robbie-bach-j-allard-peter-moore-electronic-entertainment-expoe3-2005/\#sm.0001674hbr71nd68prt1x3due0u8g

Opperman, A. (2015). Are digital badges a new measurement of mastery? Association for Talent Development. Retrieved from: https://www.td.org/Publications/Blogs/Science-of-Learning-Blog/2015/05/Are-DigitalBadges-a-New-Measurement-of-Mastery

Parker, H.E. (2015, April). Digital badges as effective assessment tools. National Institute for Learning Outcomes Assessment. Retrieved from: http://www.learningoutcomesassessment.org/documents/Assessment_in_Practice_Digital_Badges.pdf 